\title{
The Superoxide Dismutase Mimetic TEMPOL and Its Effect on Retinal Ganglion Cells in Experimental Methanol-Intoxicated Rats
}

\author{
Bambang Setiohadji - Irawati Irfani · Maula Rifada - Rova Virgana •
}

Arief S. Kartasasmita (D)

Received: March 17, 2018 / Published online: May 24, 2018

(C) The Author(s) 2018

\section{ABSTRACT}

Introduction: The incidence of blindness due to methanol intoxication is higher in males of productive age. The management of methanolinduced toxic optic neuropathy is yet to produce satisfactory results. Antioxidant therapy is now used as an alternative method of preventing methanol intoxication. The aim of this study was to observe the effect of TEMPOL (4hydroxy-2,2,6,6-tetramethylpiperidinyl-1oxyl), a superoxide dismutase (SOD) mimetic, on retinal ganglion cells in methanol-intoxicated rats.

Methods: This experimental study was conducted with 20 male Wistar rats that were 10-12 weeks old and weighed 300-350 g. The rats were divided into four groups that each received a different treatment: a negative control group, a positive control group, a methanol group, and a methanol + TEMPOL group. Enucleated eyes

Enhanced digital features To view enhanced digital features for this article go to https://doi.org/10.6084/ m9.figshare.6159821.

B. Setiohadji · I. Irfani - M. Rifada - R. Virgana .

A. S. Kartasasmita $(\square)$

Ophthalmology Department, Universitas

Padjadjaran, Bandung, Indonesia

e-mail: a.kartasasmita@unpad.ac.id

B. Setiohadji · I. Irfani · M. Rifada · R. Virgana .

A. S. Kartasasmita

Cicendo National Eye Hospital, Bandung, Indonesia from all groups were sliced and stained using hematoxylin-eosin (HE). Retinal layer and ganglion cells were assessed based on cellular structure, cellular swelling, and vacuole formation in the ganglion cell layer as observed at $\times 200$ magnification. The Kruskal-Wallis test and the Mann-Whitney test were used, with significance taken to correspond to $p<0.05$.

Results: Retinal ganglion cells of the control group had fewer vacuoles and a more well-organized cellular structure compared to those of the methanol group. The histopathologic scores of the methanol-intoxicated group were lower than those of the TEMPOL therapy group; $p=0.011$ (i.e., $p<0.05$ ).

Conclusions: TEMPOL had a positive impact on the cellular structure of retinal ganglion cells in methanol-intoxicated rats.

Keywords: Methanol-induced optic neuropathy; Retinal ganglion cells; Superoxide dismutase mimetic

\section{INTRODUCTION}

Methanol intoxication can cause various health problems such as optic neuropathy, gastrointestinal problems, and metabolic acidosis leading to death. The abuse of methanol (as a substitute for alcohol) was reported for the first time in 1904, and its incidence is rising. 
Blindness is a common outcome of methanol intoxication $[1,2]$.

The incidence of optic neuropathy due to methanol intoxication is increasing in developing countries such as Indonesia and Tunisia $[3,4]$. Studies have found that males of productive age are the population most affected by blindness due to methanol intoxication [5].

As yet, therapy for methanol-induced toxic optic neuropathy has not yielded satisfactory results. Steroid therapy and vitamin supplementation have been found to have no significant effect. Different outcomes are observed for different individuals, and a therapeutic mechanism has not been identified. Methanol intoxication leads to oxidative stress and mitochondrial dysfunction, which in turn results in ganglion cell and optic nerve necrosis.

Antioxidant therapy that inhibits the oxidative stress reaction is now being used as an alternative method of preventing methanol intoxication. The enzyme superoxide dismutase (SOD) is an antioxidant that is used to treat nerve cell degeneration. TEMPOL (4-hydroxy2,2,6,6-tetramethylpiperidinyl-1-oxyl) is a SOD mimetic that has been proven to have a neuroprotective effect. The study reported in the present paper investigated the antioxidant effect of this SOD mimetic on the histopathological profile of retinal ganglion cells in methanol-intoxicated rats.

\section{METHODS}

This experimental study was conducted with 20 Wistar rats that were $10-12$ weeks old and weighed $300-350 \mathrm{~g}$, so clinical trial registration was not conducted given that no human subjects were involved in the study. The Ethical Committee of the Faculty of Medicine at Universitas Padjadjaran approved the study. All institutional and national guidelines for the care and use of laboratory animals were followed. The rats were divided into four groups: a negative control group (no exposure), a positive control group (exposed to $\mathrm{N}_{2} \mathrm{O}: \mathrm{O}_{2}=1: 1$ flowing at $2 \mathrm{~L} / \mathrm{min}$ for $16 \mathrm{~h}$ ), a methanol group (exposed to $\mathrm{N}_{2} \mathrm{O}: \mathrm{O}_{2}=1: 1$ and methanol $3 \mathrm{~g} / \mathrm{kg}$-BW orally after $4 \mathrm{~h}$ ), and a methanol + TEMPOL group (exposed to $\mathrm{N}_{2} \mathrm{O}: \mathrm{O}_{2}=1: 1$, methanol $3 \mathrm{~g} / \mathrm{kg}-\mathrm{BW}$ orally $4 \mathrm{~h}$ later, and TEMPOL $30 \mathrm{mg} / \mathrm{kg}-\mathrm{BW} 12 \mathrm{~h}$ after that). Rats receiving the gas mixture were placed inside a glass box and given gas as per their group. The control group was enucleated $16 \mathrm{~h}$ after the start of the experiment, whereas the methanol only and the methanol + TEMPOL group were enucleated $22 \mathrm{~h}$ after the start of treatment. This method was based on that used in a previous study in which TEMPOL was applied in cases of optic nerve trauma and tests were performed $22 \mathrm{~h}$ after the start of treatment $[6,7]$. All animal models were sacrificed after enucleation. Enucleated eyes were sectioned in paraffin blocks with the cornea facing upward. The blocks were sliced to a thickness of $4 \mu \mathrm{m}$ into sagittal sections with a keratome. The slices were placed in a water bath and mounted on a microscope slide. Specimens were dried and stained with hematoxylin-eosin (HE). One certified anatomical pathologist examined the retinal layer and retinal ganglion cells using an image-multiplier light microscope (Olympus $^{\circledR}$ BX21) at $\times 200$ magnification. Retinal ganglion cells were assessed based on the regularity, swelling, and vacuolation of ganglion cells observed at $\times 200$ magnification, as explained elsewhere. Each of these parameters was scored based on a scale of $0-5$, as shown in Table 1 [8].

In this study, the sample size was calculated using Federer's formula: $(t-1)(n-1)>15$ ( $t=$ number of experimental groups; $n=$ number of samples in each group). Feeding the appropriate values into the formula results in $(3-1)(n-1)>15$, i.e., $n=8$. However, given the ethical principles for animal experiments outlined in the Helsinki Declaration, the sample size was reduced to five per group [9, 10]. Statistical analysis was performed using the Kruskal-Wallis test and the Mann-Whitney test; a $p$ value $<0.05$ was considered to indicate significance.

\section{RESULTS}

Layers of retina near the optic disc in sagittal sections of rat eyeballs were examined histopathologically. Assessment was based on 
Table 1 Possible scores in retinal ganglion cell assessment

\begin{tabular}{ll}
\hline $\begin{array}{l}\text { Histopathological observations for retinal } \\
\text { ganglion cells }\end{array}$ & Score \\
\hline $\begin{array}{ll}\text { Normal structure }^{\mathrm{a}} \text { and no swelling } \\
\text { Structural abnormality in }<50 \% \text { of cells, 20\% of }\end{array}$ & 4 \\
$\quad$ cells show swelling, vacuolation $<50 \%{ }^{\mathrm{c}}$ & 5 \\
$\begin{array}{l}\text { Structural abnormality in } 50-80 \% \text { of cells, }<50 \% \\
\text { of cells show swelling, vacuolation }<50 \%\end{array}$ & 3 \\
$\begin{array}{l}\text { Structural abnormality in }>80 \% \text { of cells, }<50 \% \\
\text { of cells show swelling, vacuolation }<50 \%\end{array}$ & 2 \\
$\begin{array}{l}\text { Structural abnormality in }>80 \% \text { of cells, }>50 \% \\
\text { of cells show swelling, vacuolation }>50 \%\end{array}$ & 1 \\
\hline
\end{tabular}

a Normal structure: ganglion cells occur in a regular linear arrangement with no aberrant cells apparent

b Swelling: ganglion cells appear significantly edematous

c All percentages are estimated from the mean of three high-power fields of each slide

the structure, swelling, and vacuolation of retinal ganglion cells. The examiner observed less vacuole formation in the $K_{0}$ (negative control) group and the $K_{1}\left(\mathrm{~N}_{2} \mathrm{O}: \mathrm{O}_{2}\right)$ group than in the $K_{2}$ (methanol only) and $K_{3}$ (methanol + TEMPOL) groups. The retinal ganglion cell layer (GCL), internal nuclear layer (INL), and outer nuclear

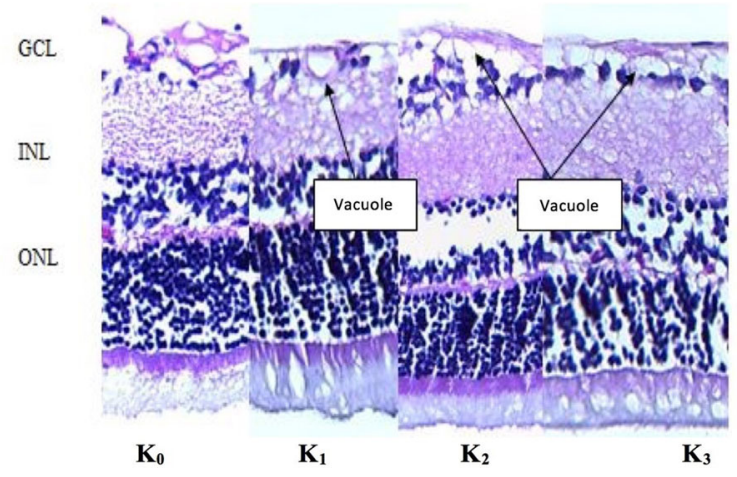

Fig. $1 \mathrm{HE}$ staining of the retinal ganglion cell layer. Retinal ganglion cell layers of the $K_{0}$ and $K_{1}$ groups show less vacuolation than those layers in the $K_{2}$ and $K_{3}$ groups. Better cellular structures and cell layers were seen for the GCL, INL, and ONL in the $K_{0}, K_{1}$, and $K_{3}$ groups. $G C L$ ganglion cell layer, $I N L$ internal nuclear layer, $O N L$ outer nuclear layer layer (ONL) were found to be well ordered in the non-methanol $\left(K_{0}\right.$ and $\left.K_{1}\right)$ groups and the TEMPOL $\left(K_{3}\right)$ group, as shown in Fig. 1.

The histopathological examination yielded a lower score for the treated group $\left(K_{3}\right)$ than for the negative control group $\left(K_{0}\right.$, the normal score reference) and the positive control group $\left(K_{1}\right.$, the acidosis score reference), as shown in Fig. 2.

Low scores were obtained upon histopathological examination of the methanol-intoxicated group $\left(K_{2}\right)$ and the methanol + TEMPOL group $\left(K_{3}\right)$, although the score for $K_{3}$ was higher than that for $K_{2}$. Statistical analysis of these scores using the Kruskal-Wallis test suggested that the scores for the groups were significantly different $(p=0.011)$, as shown in Table 2 .

\section{DISCUSSION}

Methanol intoxication causes acidosis. $\mathrm{HCO}_{2}$ can easily pass through the ganglion cell wall, leading to the following formate oxidation reaction in the mitochondria and lysosome:

$$
\begin{aligned}
& \mathrm{HCOO}^{-} \text {or } \mathrm{HCO}_{2}^{-}+ \\
& \mathrm{H}_{4} \text { folate } \stackrel{10-\text { formyl }_{4} \text { Folatesynthase }_{\longrightarrow}}{\rightarrow} 10 \text {-formyl } \mathrm{H}_{4} \text { folate } \\
& \begin{array}{l}
\text { 10-formyl } \mathrm{H}_{4} \text { folate } \stackrel{10-\text { formylH }_{4} \text { Folatedehydrogenase }}{\rightarrow} \mathrm{CO}_{2} \\
+\mathrm{H}_{2} \mathrm{O}
\end{array}
\end{aligned}
$$

In rats, the oxidative reaction of formate is twice as fast as it is in humans. Thus, formate has a greater tendency to accumulate in the human body than in rats. During this formate oxidation reaction, $\mathrm{O}-\mathrm{H}$ bonds are more likely to break when the body is in a state of methanol intoxication. Problems with electron transport lead to inefficient ATP synthesis and a higher concentration of reactive oxygen species (ROS). This in turn results in a higher rate of oxidative destruction of mitochondrial molecules. The electron transport chain in the inner mitochondrial membrane is involved in ATP synthesis through the intracellular respiration system. Decreased ATP and ADP in the mitochondria of retinal ganglion cells causes photoreceptor structure and function 


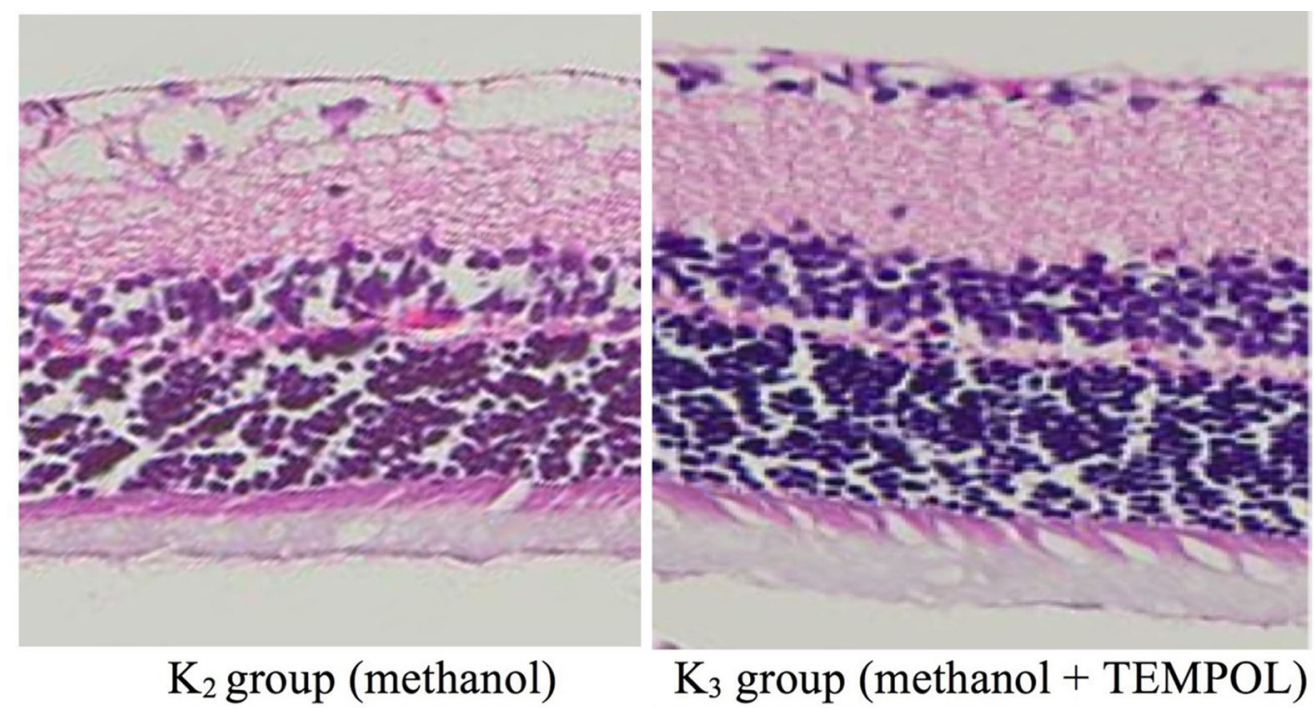

Fig. 2 Comparison of the results of histopathological examinations of retinal ganglion cells from two of the groups. The cellular structure, internal cell layer, and outer cell layer of the $K_{3}$ group were better than those of the $K_{2}$ group

Table 2 Results of histopathological analyses of ganglion cell layers from the four groups

\begin{tabular}{lllllll}
\hline Variable & $\begin{array}{l}\boldsymbol{K}_{\mathbf{0}} \\
(\boldsymbol{n}=\mathbf{5})\end{array}$ & $\begin{array}{l}\boldsymbol{K}_{\mathbf{1}} \\
(\boldsymbol{n}=\mathbf{5})\end{array}$ & $\begin{array}{l}\boldsymbol{K}_{\mathbf{2}} \\
(\boldsymbol{n}=\mathbf{5})\end{array}$ & $\begin{array}{l}\boldsymbol{K}_{\mathbf{3}} \\
(\boldsymbol{n}=\mathbf{5})\end{array}$ & $\begin{array}{l}\boldsymbol{X}^{\mathbf{2}} \\
\mathbf{K}-\mathrm{W}\end{array}$ & $\boldsymbol{p}$ value \\
\hline Minimum & 8 & 6 & 3 & 4 & 11.102 & 0.011 \\
Maximum & 9 & 8 & 8 & 8 & & \\
Median & 9 & 6 & 4 & 7 & & \\
\hline
\end{tabular}

$K_{O}$ negative control group, $K_{1} \mathrm{~N}_{2} \mathrm{O}$ group, $K_{2}$ methanol group, $K_{3}$ methanol + TEMPOL group

$X_{\mathrm{K}-\mathrm{W}}^{2}=$ Kruskal-Wallis test

impairment and thus weakens the attachment of the photoreceptors to the retinal pigment epithelium [11].

Formate accumulation causes the formation of $\mathrm{CO}_{2}+\mathrm{H}_{2} \mathrm{O}$, and this $\mathrm{H}_{2} \mathrm{O}$ causes the retina to swell. The degree of vacuolation in the methanol group $\left(K_{2}\right)$ was significantly higher than that in the methanol plus antioxidant group $\left(K_{3}\right)$. Regular cellular structure was seen in the samples from group $K_{3}$ (Fig. 1). There was no significant difference between the thicknesses of the INL and ENL in those groups; this was assumed to be due to balanced COX and SDH activity in both layers [11].

The antioxidant TEMPOL is a stable nitrite oxide radical that resembles SOD [12]. This substance passes through the blood-brain barrier and ocular tissues easily. In this study, TEMPOL was given $12 \mathrm{~h}$ after methanol administration to the Wistar rats in group $K_{3}$. This study found that the histologic structure of retinal tissue improved after the administration of TEMPOL (Fig. 2), showing that the antioxidant TEMPOL can decrease the concentration of free radicals while acting as a neuroprotector in methanol intoxication, leading to better cellular structure. Thaler et al. [13] found TEMPOL to be an effective neuroprotector in cases of brain trauma, ischemic stroke, and Parkinson disease. TEMPOL was also found to act as a neuroprotector in rats with optic neuron impairment [7]; that observation agrees with the results of this study, in which we found that, in cases of toxic methanol optic neuropathy, the cellular 
structure of the retinal ganglion cells improved after the administration of TEMPOL [13].

Limitations of this study include the short observational period and the small sample size. Also, the slides were examined by only one certified anatomical pathologist, so there was no test/retest variability in this study. This study could be improved by including more samples, expanding the duration of TEMPOL administration, lengthening the observational period, and incorporating slide examination variability.

\section{CONCLUSIONS}

In conclusion, the administration of the SOD mimetic TEMPOL had a significant positive effect on the structure of retinal ganglion cells in methanol-intoxicated rats. Antioxidant therapy shows considerable potential as a possible future therapy for methanol-induced toxic optic neuropathy.

\section{ACKNOWLEDGEMENTS}

Funding. The authors hereby acknowledge the receipt of a Universitas Padjadjaran Research Internal Grant for this study. No funding was received for the publication of this article.

Authorship. All named authors meet the International Committee of Medical Journal Editors (ICMJE) criteria for authorship for this article, take responsibility for the integrity of the work as a whole, and have given their approval for this version to be published.

Author Contributions. Category 1: (a) concept and design: all authors; (b) acquisition of data: BS; (c) analysis and interpretation of data: BS. Category 2: (a) drafting of manuscript: II, $\mathrm{RV}, \mathrm{MR}$; (b) revision of manuscript for intellectual content: all authors. Category 3: (a) final approval: AK.

Non-Author Contributions. The authors hereby acknowledge Bethy S. Hernowo, who served as a participating investigator, and Adinda C.D. Nugraheni, who participated in the writing and technical editing of the manuscript.

Disclosures. Bambang Setiohadji, Irawati Irfani, Arief S. Kartasasmita, Maula Rifada, and Rova Virgana have nothing to disclose.

Compliance with Ethics Guidelines. The ethics committee of the Medical Faculty of the Universitas Padjadjaran approved this study. All institutional and national guidelines for the care and use of laboratory animals were followed during the study.

Open Access. This article is distributed under the terms of the Creative Commons Attribution-NonCommercial 4.0 International License (http://creativecommons.org/licenses/ by-nc/4.0/), which permits any noncommercial use, distribution, and reproduction in any medium, provided you give appropriate credit to the original author(s) and the source, provide a link to the Creative Commons license, and indicate if changes were made.

\section{REFERENCES}

1. Burkhart KK, Kulig KW. The other alcohols. Methanol, ethylene glycol, and isopropanol. Emerg Med Clin North Am. 1990;8(4):913-28.

2. Tanrivermis Sayit A, Aslan K, Elmali M, Gungor I. Methanol-induced toxic optic neuropathy with diffusion weighted MRI findings. Cutan Ocul Toxicol. 2016;35(4):337-40.

3. Brahmi N, Blel Y, Abidi N, et al. Methanol poisoning in Tunisia: report of 16 cases. Clin Toxicol (Phila). 2007;45(6):717-20.

4. Ardiella YNY, Sidik M. Methanol toxic optic neuropathy characteristic and evaluation of therapy. Ophthalmol Indones. 2016;45(1):2.

5. Rotenstreich Y, Assia EI, Kesler A. Late treatment of methanol blindness. $\mathrm{Br} \mathrm{J}$ Ophthalmol. 1997;81(5):416-7.

6. Lindsey JD, Duong-Polk KX, Dai Y, Nguyen DH, Leung CK, Weinreb RN. Protection by an oral disubstituted hydroxylamine derivative against loss of 
retinal ganglion cell differentiation following optic nerve crush. PLoS One. 2013;8(8):e65966.

7. Tanito M, Li F, Elliott MH, Dittmar M, Anderson RE. Protective effect of TEMPOL derivatives against light-induced retinal damage in rats. Invest Ophthalmol Vis Sci. 2007;48(4):1900-5.

8. El-Bakary AA, El-Dakrory SA, Attalla SM, Hasanein NA, Malek HA. Ranitidine as an alcohol dehydrogenase inhibitor in acute methanol toxicity in rats. Hum Exp Toxicol. 2010;29(2):93-101.

9. WHO. General guidelines for methodologies on research and evaluation of traditional medicine. Geneva: WHO; 2000.
10. Eckelman WC, Kilbourn MR, Joyal JL, Labiris R, Valliant JF. Justifying the number of animals for each experiment. Nucl Med Biol. 2007;34(3):229-32.

11. Skrzydlewska E. Toxicological and metabolic consequences of methanol poisoning. Toxicol Mech Methods. 2003;13(4):277-93.

12. Fukai T, Ushio-Fukai M. Superoxide dismutases: role in redox signaling, vascular function, and diseases. Antioxid Redox Signal. 2011;15(6):1583-606.

13. Thaler S, Fiedorowicz M, Rejdak R, Choragiewicz TJ, et al. Neuroprotective effects of tempol on retinal ganglion cells in a partial optic nerve crush rat model with and without iron load. Exp Eye Res. 2010;90:254-60. 